\title{
Study on the Path to Improve Counselors' Professional Ability from the Perspective of Supply-Side Reform
}

\author{
Yuxi Niu \\ Student Affairs Office of School of Civil Engineering and Architecture \\ Wuhan University of Science and Technology \\ Wuhan, China
}

\begin{abstract}
Since the 18th national congress of the communist party of China (CPC), a great upsurge of supply-side reform has been launched in the national economic field, and remarkable achievements have been made. People's happiness has been significantly improved. The idea of supply-side reform is also of reference to the work of college students. As the supply side of college students' work, the improvement of counselors' professional ability will directly determine the sense of acquisition and happiness of students on their way to growth and talent. By analyzing the characteristics of modern college students and their growth needs, this paper aims to improve the counselors' professional ability from five aspects, such as supply concept, supply content, supply mode, supply quality and supply environment. From the perspective of supply-side reform, improving counselors' professional ability will make students' work more targeted and effective.
\end{abstract}

Keywords-supply-side reform; The counselor; Professional ability; ascension

\section{INTRODUCTION}

Since the 18th national congress of the CPC, the collective leadership of the CPC central committee with comrade $\mathrm{Xi}$ Jinping as the core has proposed the concept of supply-side reform in view of the domestic economic development. So what is supply-side reform? Supply-side reform is to expand effective supply from the perspective of improving the quality of the supply side, so as to promote economic growth and meet the needs of the people. In short, to improve the service quality and efficiency of the service side, so as to better meet the needs of the service side. Through the five years of supply-side reform, China's economic situation has made a qualitative leap, and people's sense of gain and satisfaction has reached the previous level.

The sense of happiness and satisfaction brought by the supply-side reform to the national life is associated with the work of college students, especially counselors, which has the same reference significance. College is an important milestone in the life of young students. Entering a college campus as an adult is not only a successful transformation but also a brand new start for young college students. It is a crucial period for the healthy development of students' body and mind and the formation and establishment of values. In his speech, comrade $\mathrm{Xi}$ Jinping stressed that young college students should fasten "the first button of life". As the first station after students become adults, colleges and universities shoulder the historical mission of teaching and educating people. Organizers and implementers, as a student of university counselors work directly in the face of the broad masses of young students, help them to set up the correct values, to guide college and career planning, both ideological capacity requirements, at the same time have the ability of specialized professional requirements, on the supply side of reform of the horizon, it puts forward new requirements to the counselor's professional ability.

\section{The Practical SignificANCE OF SUPPLY-SidE REFORM IN STUDENT WORK}

\section{A. The new era and new thoughts require the reform of college student work}

Since the 18th national congress of the communist party of China (CPC), general secretary Xi Jinping has attached great importance to the development of China's higher education and ideological and political education in colleges and universities, and published a series of important dissertations. In his important speech, general secretary Xi Jinping stressed that we should adhere to the cultivation of moral integrity as the central link, put ideological and political work through the whole process of education and teaching, realize the whole process of educating people, and strive to create a new situation in the development of China's higher education [1]. Xi Jinping thought on socialism with Chinese characteristics for the new era requires colleges and universities to help young college students establish correct mainstream ideology, and the specific implementer of this work is a counselor. College counselors are not only the practitioners of the socialist mainstream ideology, but also the disseminators of the socialist mainstream ideology in colleges and universities. College stage is the key period for the formation and establishment of the ideology of young college students, and it is very important to pay attention to the value cultivation in this period. As an effective way to carry out ideological education, counselors have become an indispensable part of the educational management of young students. In the new historical period, counselors as the supply side need to improve their ability under the guidance of new ideas. 


\section{B. The counselor's job responsibility deepens puts forward the new request}

Since the 18th national congress of the communist party of China (CPC), with the deepening reform of the education system, new goals and requirements have been put forward for the construction of the counselor team. According to the high school counselor professional ability standard (tentative) "the relevant requirements, need in the ideological and political education of university counselors, group and class construction, academic guidance, psychological health education and consulting, career planning and employment guidance, and nine aspects of the corresponding knowledge reserve and ability, these a few respects, both in education management and guidance services related to student affairs ability, also includes the self-building related scientific research ability of learning. To strengthen the construction of the counselor team, it is necessary to study and improve from the above aspects, improve their theoretical level and service ability, so as to carry out targeted work. By deepening the counselor's job responsibilities, and promote headteachers to specialization, the direction of professional development, the problems for students, and can give professional guidance and services, improve the students' actual in campus life and the feeling of satisfaction, truly make it becomes the real guidance and leading students to life on the road.

\section{To meet the characteristics and individual needs of young college students}

At present, college students are post-90s or even post-00s. They are passionate and energetic, and their thoughts are in an extremely active state. Their value orientation determines the value orientation of the whole society in the future, so it is the primary task of higher education to help them establish correct values[2]. Secondly, the growing environment of contemporary college students is quite different from that before, especially the access to information is very smooth, so how to enable students to obtain more and deeper information on campus, also puts forward new requirements on the professional ability of counselors. Traditional educational concepts and methods can not meet their needs. Moreover, the growth experience of college students determines the outstanding and strong personality of each student. How to carry out personalized guidance to promote the growth and talent of students has become an urgent problem to be solved by college counselors.

\section{THE IMPROVEMENT PATH OF COUNSELORS' Professional ABILITY From the PERSPECTIVE OF SUPPLY-SIDE}

To sum up, no matter in the background of The Times, the deepening of counselors' responsibilities or the needs of students' own development, new requirements and hopes are put forward for the content and quality of the supply that counselors can provide in the process of carrying out students' work. From the perspective of supply-side reform, counselors' professional ability should grasp the characteristics of The Times, the characteristics of students and the improvement of their own professional ability, and improve in five aspects, such as supply concept, supply content, supply mode, supply quality and supply environment[3].

\section{A. Changing the role positioning, open and diversified supply concept}

In the traditional mode of student work, counselors, as managers, have the absolute right to speak, and students' work focuses on management. They only communicate requirements and regulations related to the school, seldom listen to the real needs of students, and sometimes impose values. From the perspective of the supply side, to improve the professional ability of counselors, the first thing to change is their own concept, please come down from the high platform, in terms of identity, from a preacher to a server; In the nature of the work, there is a shift from management to service delivery. Move the work pass to the student group, and students become one, do students intimate friends, on the one hand to understand the students, familiar with the students, do know each student's personality characteristics; On the other hand, it can timely find the confusion students encounter in work, study and life, and provide professional guidance and help to help students successfully complete the transition from students to society. Secondly, it is necessary to give full play to the subject status of students, stop the traditional teaching mode of education, give full play to the subjective initiative of self-management, self-education and self-growth of college students, and inspire and guide students to explore solutions to problems by carrying out diversified activities [4]. Counselors play the role of gardeners and deal with the cognitive deviations and improper behaviors of students in the process of solving problems in time, so as to help students form correct values and ways of doing things.

\section{B. Grasping the personalized needs of students, rich and diverse supply}

The era and growing environment of contemporary college students determine their individual development. They have a strong sense of independence and have different views and choices for their own development. The essence of a college education is not to cultivate and duplicate the same talents. Colleges and universities should be student-oriented and encourage college students to plan their own growth according to their interests and specialties. Therefore, the content that counselors can provide for students needs to be rich and varied, which can meet the requirements of different students in the process of growth, provide targeted services, improve students' sense of acquisition on the road of growth and talent, and help students to complete their own personality development. This requires counselors to first understand the basic situation of students, master the students' personality and characteristics, it is best to be able to establish relevant files to facilitate the pertinence and convenience of later tutoring work. Secondly, we should strengthen the accumulation of our own knowledge reserves. There are various problems in students' growth path, covering all aspects of life. This requires counselors to be thoughtful, good at accumulation and expansion, so that students can not only chat but also gain. According to their actual situation, special students, such as students with financial difficulties and students with psychological problems, should not only give corresponding help and support, but also popularize corresponding mental health education knowledge and do a good job in psychological dredging. 


\section{Innovating the way of supply to meet the needs of young people.}

In an era of rapid development of information technology, simple face-to-face preaching and imparting cannot meet the needs of young students for information acquisition. However, the emerging new media is characterized by strong interest, high interactivity and diverse forms, and has gradually developed into an information medium more popular with young students. Therefore, as counselors, they should also learn how to use new media in information supply. Through innovative forms, teaching through lively activities, they can really show their opinions in the way they like. Secondly, in the era of we-media, counselors should give full play to the advantages of the main position of the network. They can sort out the possible confusion on the way of students' growth and becoming talents by writing blog posts and tweets, and answer questions according to experience and relevant theoretical systems. Give full play to the role of the second classroom, through the organization of cultural and sports activities, science and technology competitions, volunteer service, quality development and other activities that students like, cultivate students' comprehensive ability, improve students' core competitiveness.

\section{Improving the quality of supply to meet students' sense of acquisition.}

Counselors need to provide students with relevant professional services in nine aspects, such as mental health, academic guidance and career planning. Therefore, counselors are required to master necessary knowledge, enhance their theoretical knowledge learning, and improve their theoretical level through systematic learning and relevant training. At the same time, I pay attention to the combination of theory and practice, make reasonable use of what I have learned in work, summarize and conclude, and improve my professional ability. Strengthen the communication between the college counselor, by organizing the counselor salon seminars and lectures, communicate with each other good experience and practices, improve the working process and system, in view of the problems of the students in different growth stage, all ideas brainstorming, improve their ability at the same time, improve the core of the counselor team combat effectiveness.

\section{E. Improving the supply environment and improve students' enthusiasm.}

At present, people have a big misunderstanding on the working environment of counselors, believing that all the work related to students should be completed by counselors. Therefore, counselors are surrounded by a lot of routine work, and there is no way to improve theoretical study and professional ability. In view of this problem, counselors need to free themselves from a lot of routine work, really go deep into students, communicate with students more, try to think from the perspective of students, understand what students think, so as to improve work efficiency. In addition, it is necessary to create a good educational environment. Through publicity and activities, students can truly understand the benefits brought by the second class and other contents to students. At the same time, students are actively encouraged to innovate and independently carry out all kinds of activities conducive to the physical and mental development of college students, so as to improve the enthusiasm and enthusiasm of students to participate.

\section{CONCLUSION}

In the report to the 19th national congress of the communist party of China (CPC), the general secretary once again stressed that a strong country is only as strong as its young people. In the new historical period, college counselors bearing the important task of educating people, the improvement of their professional ability is also imminent. From the perspective of supply-side reform, the work philosophy of counselors should be changed to improve their professional ability, so as to carry out targeted student work and help students grow and become talents.

\section{REFERENCES}

[1] Xiaoxu Yang, "Reflections on the ideological and political education work of cultivating people by virtue"[J] New West, pp. 117-118, March 2017.

[2] Xiaojun Li, "Value dilemma and path of supply-side reform of college student work" [J] Journal of Changsha University of Technology (Social Science Edition), pp. 126-129, May 2017.

[3] Qijun Liu, Yang Zhang, "Some thoughts on integrating socialist core values into party construction in colleges and universities" [J] Journal of Social Sciences, Hunan Normal University, pp. 66-70, April 2017.

[4] Yang Zhou, "Give Full Play to the Main Role of College Students in Ideological and Political Education" [J] Curriculum Education Research (New Teacher Teaching), pp. 87, 2016. 